\title{
Free-living diazotrophs drive castor bean nitrogen input in tropical semiarid soils
}

\author{
Felipe José Cury Fracetto ${ }^{1^{*}}$ (iD) Giselle Gomes Monteiro Fracetto ${ }^{1}$ (D) \\ Felipe Martins do Rêgo Barros ${ }^{1}$ (D) Mario de Andrade Lira Junior ${ }^{1}$ (D) Marcos Siqueira Neto ${ }^{2}$ (D) \\ ${ }^{1}$ Universidade Federal Rural de Pernambuco (UFRPE), 52171900, Recife, PE, Brasil. \\ ${ }^{2}$ Centro de Energia Nuclear na Agricultura, Universidade de São Paulo (CENA/USP), Piracicaba, SP, Brasil. E-mail: curyfelipe@hotmail.com. \\ ${ }^{*}$ Corresponding author.
}

\begin{abstract}
There are few studies of microbial diversity in castor bean soils in tropical semiarid environmental. Castor bean products have been widely used around the world justifying the commercial importance of ricinoculture in Brazil' northeastern semiarid. There is no fertilization or maintenance of litter on the soils from the present study, so we hypothesized that the free-living diazotrophs microorganisms drive the nitrogen (N) input into these soils. We evaluated the communities'structure and diversity of diazotrophs in tropical semiarid soils with i-Castor bean 50 years of cultivation intercropping with maize (CB-50); ii-Only Castor bean 10 years of cultivation (CB-10) and iii-soil under Caatinga vegetation (CAA). Nitrogenase enzyme activity was performed by the acetylene reduction assay (ARA) and the community profile of nifH gene was separated by denaturing gradient gel polyacrylamide electrophoresis (DGGE). Diazotrophs diversity was estimated by the Shannon ( $\left.H^{\prime}\right)$ and Simpson (D) indexes. Based on the maintenance of soil $N$ stocks and $N$-microbial biomass over time, the activity of free-living diazotrophs was determinant in the $N$-input into these soils. The nifH gene was present and its profiles grouped the CB-50 with $C A A$ treatments, so it reinforced the $N$-fixing by diazotrophs, which presented a greater diversity in the cultivated soils, even after the land use change for the castor bean implementation.

Key words: nifH, microorganism diversity, ricinoculture, Caatinga dry forest.
\end{abstract}

Diazotróficas de vida livre conduzem a entrada de nitrogênio em solos cultivados com mamona no semiárido

RESUMO: Existem poucos estudos sobre a diversidade microbiana em solos de mamona no ambiente semiárido tropical. Os produtos de mamona têm sido amplamente utilizados em todo o mundo e justificam a importância comercial da ricinocultura no semiárido nordestino brasileiro. Como não há qualquer tipo de fertilização, ou manutenção de resíduos da cultura nos solos de mamona do presente estudo, presume-se que a comunidade de diazotróficas forneça o nitrogênio (N) nesses solos. Avaliou-se a estrutura e diversidade de comunidades de diazotróficas em solos de mamona do semiárido tropical em: i-Mamona com 50 anos de cultivo, consorciada com milho (CB-50); ii-Mamona com 10 anos de cultivo sem consórcio (CB-10) e iii-solo sob vegetação de Caatinga preservada (CAA). Realizou-se avaliação de redução do acetileno a etileno (ARA) e o perfil do gene nifH foi separado por eletroforese em gel de poliacrilamida com gradiente desnaturante (DGGE). A diversidade de diazotróficas foi estimada pelos índices de Shannon ( $\left.H^{\prime}\right)$ e Simpson (D). Com base na manutenção dos estoques de nitrogênio no solo e da biomassa microbiana ao longo do tempo, a atividade dos diazotróficos de vida livre foi determinante na entrada de $N$ nesses solos. $O$ gene nifH esteve presente e seus perfis agruparam os tratamentos CB-50 com CAA, reforçando a fixação de $N$ pelos diazotróficos, os quais apresentaram maior diversidade nos solos cultivados, mesmo após a mudança de uso da terra para o plantio de mamona.

Palavras-chave: nifH, diversidade microbiana, ricinocultura, Caatinga.

\section{INTRODUCTION}

The castor bean (Ricinus communis L) is an oilseed of the Euphorbiaceae family and has xerophilic plant characteristic with good adaptation in different climatic conditions. Castor oil is the most important constituent of the castor seeds, containing about $90 \%$ of ricinoleic fatty acid, constituting an industrial use diversity (ZHANG et al., 2016). The castor bean has a relevant socioeconomic role for the Brazil northeastern semiarid supported by small farmers, where Bahia state is the largest national producer of berries, responsible for $80 \%$ of all Brazilian production (IBGE, 2017).

There are studies involving the carbon and nitrogen cycling in castor bean soils (FRACETTO et al., 2012; FRACETTO et al., 2015), but the structure and diversity of the free-living diazotrophs in these 
soils are still unknown. The diazotrophs species have been identified in diverse taxonomic groups that storage $\mathrm{N}$ into the soil and according to WANG et al. (2017), N-storage by Archaea domain was limited to the Euryarchaeota phylum, but 13 phyla from Bacteria domain can drive the $\mathrm{N}$-input in the soil. During the biological nitrogen fixation (BNF), the nifH gene encodes the iron-protein or component II, i.e. a homodimer from the nitrogenase complex. The nitrogenase enzyme is necessary to break the $\mathrm{N}_{2}$ triple bond and it reducing this molecule to ammonia and consuming ATP (KACZMAREK et al., 2018).

The nifH amplicons can be separated by the denaturing gradient gel polyacrylamide electrophoresis (DGGE) technique and effectively showed the diazotrophs community profile in the soils under different climatic conditions, management types at different growing seasons. In addition, the DGGE results can provide an estimate of these organisms diversity, allowing the study of microorganism behavior in the soil through the specific diversity indexes for each gene (SCHLOTER et al., 2018).

Shannon and Simpson indexes (SHANNON \& WEAVER, 1963; SIMPSON, 1949) are the main tools for estimating biodiversity in environmental samples using in the evaluation of microorganisms communities. The Simpson or dominance index considers that diversity is inversely related to the probability that two individuals randomly assigned to one community belong to the same species (SIMPSON, 1949). Shannon's index measures the uncertainty degree in predicting which species belongs to a randomly chosen individual in a community (SHANNON; WEAVER, 1963). In the latter case, the diversity tends to be higher when the value of the index is raised.
Considering the land use change for castor bean implementation and the absence of agricultural inputs or castor bean crop residues in these soils, we assumed that the diazotrophs drive the N-input into these soils. Thus, we determined de ARA assay, N-microbial biomass and we evaluated the communities' structure and diversity of diazotrophs in castor bean soils in tropical semiarid environment.

\section{MATERIALS AND METHODS}

The study was conducted at Fazenda Floresta in Irecê, north-central Bahia-Brazil (11 $18^{\prime} 14^{\prime \prime} \mathrm{S}$ and $\left.41^{\circ} 51^{\prime} 21^{\prime \prime} \mathrm{W}\right)$. According to Köppen, the region climate is BSwh - Semiarid climate of altitude (722 meters) with average annual rainfall of $582 \mathrm{~mm}$, with rains from November to January. The average annual temperature is $22.7^{\circ} \mathrm{C}$, ranging between 17.7 and $26.9^{\circ} \mathrm{C}$. The soil has been classified as Red Latosol of clayey texture (Typic Haplustox; Soil Survey Staff, 2014) and some physical and chemical features are described on table 1 .

Castor bean cultivars used were both BRSNordestina and BRS-Paraguaçu, which have good resistance to pests or diseases and its seeds produce a large amount of oil. The castor bean was cultivated intercropping with maize, occurring the manual pruning of castor bean curls after one year, sprouting then the following month to increase productivity. The cultivation did 2 meters between plants and 4.5-6.0 $\mathrm{m}$ between rows. In the Fazenda Floresta the castor bean crop has been conducted under a family production system, without agricultural inputs. Castor bean planting began in 1960 in the native vegetation areas (Caatinga).

Table 1 - Semiarid soils attributes at $0-20 \mathrm{~cm}$.

\begin{tabular}{|c|c|c|c|}
\hline \multirow[t]{2}{*}{ Attributes } & \multicolumn{3}{|c|}{ 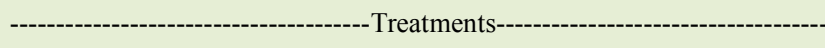 } \\
\hline & CB-10 & CB-50 & CAA \\
\hline Sand $(\%)^{1}$ & $34 \pm 25$ & $30 \pm 8$ & $30 \pm 4$ \\
\hline Silt $(\%)^{1}$ & $16 \pm 0.3$ & $16 \pm 0.4$ & $16 \pm 0.6$ \\
\hline Clay $(\%)^{1}$ & $50 \pm 0.7$ & $54 \pm 0.6$ & $54 \pm 0.4$ \\
\hline-- & 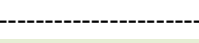 & -------------. & ------------- \\
\hline $\mathrm{pH}\left(\mathrm{H}_{2} \mathrm{O}\right)^{2}$ & $6.1 \pm 0.04$ & $6.4 \pm 0.03$ & $6.3 \pm 0.04$ \\
\hline $\mathrm{SB}\left(\mathrm{cmolc} \mathrm{kg}{ }^{-1}\right)^{3}$ & $7.2 \pm 0.02$ & $7.1 \pm 0.03$ & $7.2 \pm 0.03$ \\
\hline $\mathrm{T}\left(\mathrm{cmolc} \mathrm{kg}^{-1}\right)^{4}$ & $4.5 \pm 0.21$ & $4.2 \pm 0.14$ & $4.7 \pm 0.11$ \\
\hline
\end{tabular}

${ }^{1}$ Densimeter method (EMBRAPA, 2009). ${ }^{2,3}$ and ${ }^{4}$ (EMBRAPA, 2009). CB-10: Castor bean 10 years cultivation; CB-50: Castor bean 50 years cultivation; CAA: Caatinga vegetation; T: potential CTC; SB: sum of bases. 
The experimental design was completely randomized with five replicates. The selected areas were: Caatinga: area under native vegetation (CAA); Castor bean 50 years - castor bean intercropping with maize, since 1960 (CB-50); Castor bean 10 years - Only Castor bean cultivated since 1998, without intercropping (CB10). Samples were collected at $30 \mathrm{~cm}$ with auger and placed in sterile bags for all analyzes and maintained at $-20{ }^{\circ} \mathrm{C}$ to preserve the genetic material.

\section{Nitrogenase evaluation and N-microbial biomass}

The reduction of acetylene to ethylene (ARA) was performed to verify the BNF (BARRON et al., 2009) showing the sensitivity of the nitrogenase enzyme. Soil samples were placed in $800 \mathrm{ml}$ containers hermetically sealed and injected acetylene gas in the proportion of $10 \%$ of the total volume. After 8 hours of incubation, the gas samples were chromatographed by Trace-Analytical Science ${ }^{\circledR}$ equipment for the analysis of ethylene formation.

Nitrogen from soil microbial biomass was obtained by the extraction-fumigation method, according to VANCE et al. (1987), where N-microbial contents were quantified by the ninhydrin method (JOERGENSEN \& BROOKES, 1990).

\section{Diazotrophs community profile}

The DNA of the soil samples was extracted according to the conditions proposed in the UlraClean Soil DNA Isolation Kit (MoBio Laboratories, Carlsbad, CA). Next, the procedures for conducting Nested PCR to amplify fragments of the nifH gene from soil diazotrophs communities were performed, according to DEMBA DIALLO et al. (2004).

The primers used were FGPH19 (5'-TAC GGC AAR GGT GGN ATH G-3') (SIMONET et al., 1991) and POLR (5'-ATS GCC ATC ATY TCR CCG GA-3') (POLY et al., 2001), generating 429 bp. The second amplification was made with the primers POLF-GC (5'- CGC CCG CCG CGC CCC GCG CCC GGC CCG CCG CCC CCG CCC CTG CGA YCC SAA RGC BGA CTC-3') (POLY et al., 2001) containing a GC clamp and AQER (5'- GAC GAT GTA GAT YTC CTG-3') (POLY et al., 2001), producing 320 bp.

To separate the amplicons from the nifH gene, the DGGE was used. The acrylamide: bisacrylamide gels $8 \%(37.5: 1, \mathrm{~m}: \mathrm{m})$ were prepared with a denaturing gradient ranging from 20 to $70 \%$ using a $100 \%$ denaturing solution containing $7 \mathrm{M}$ urea and $40 \%$ formamide and a $0 \%$ solution, without urea and formamide (PEREIRA \& SILVA, 2011). Electrophoresis was performed at $200 \mathrm{~V}$ and $60{ }^{\circ} \mathrm{C}$ for 4 hours in a DCode vertical electrophoresis system
(BioRad) using 0.5 X TAE buffer solution (10 mM Tris-acetate and 0.5 mM EDTA, $\mathrm{pH} 8.0$ ).

The gel was immersed in a solution of $10 \%$ glacial acetic acid for 15 minutes on a horizontal shaker, washed three times with distilled water and immersed in 50\% methanol solution for 15 minutes, stained in SYBR-Green I solution (Molecular Probes) $(1: 10,000, v: v)$. The gel image was captured using a FluorImager (GE Healthcare) laser densitometer and the Fragment Analysis (GE Healthcare) program.

The similarity among the structures of diazotrophs communities was determined based on the presence or absence of amplicons detected after DGGE. Gels were analyzed using the Diversity Database program to determine the amplicons richness. The hierarchical grouping was performed through the Systat 8.0 program, based on similarity matrices generated by the simple matching method, using the Ward algorithm and the Euclidean distance as unit of measure. In order to verify the association of the nifH banding profiles variability, a Non-metric Multidimensional Scaling (NMDS) was carried out using the similarity values among the samples to calculate coordinates in a sort space, using the WinKyst program and the Jaccard similarity coefficient. Differences among the treatments were assessed by similarity analysis (ANOSIM).

\section{Diversity index}

Structural diversity of the diazotrophs community was evaluated by the Shannon and Simpson's indexes, using the intensity profiles and the bands number present in the gel (DGGE). Intensity was considered as the peaks height in the profile. The Shannon $\left(H^{\prime}\right)$ and Simpson $(D)$ indexes were calculated according to the following equations:

$$
H^{\prime}=-\sum_{i=1}^{i=S} p i \ln p i \quad D=\sum_{i=1}^{i=S} p i^{2}
$$

where: $n$ is the bands numbers on profile, $p i=n \mathrm{i} / \mathrm{N}$; ni is the peaks heigth and $\mathrm{N}$ is the sum of all peak heights in the profile.

\section{Statistical analysis}

Results for the Shannon and Simpson indexes, ARA and N-microbial were submitted to analysis of variance (ANOVA) and Tukey's test $(\mathrm{P}<0.05)$ was used to compare the means using SAS program (2003).

\section{RESULTS AND DISCUSSION}

According to FRACETTO et al. (2012) data, soil $\mathrm{C}$ and $\mathrm{N}$ stocks $(0-30 \mathrm{~cm})$ in the same 
areas of the present study did not show significant variation between CB-10 and CB-50 ( $\sim 40 \mathrm{Mg} \mathrm{ha}^{-1}$ of $\mathrm{C}$ and $5 \mathrm{Mg} \mathrm{ha}^{-1}$ of $\mathrm{N}$ for both ages of castor bean cultivation) and it remaining constant over time among the different ages of castor bean evaluated. However, the soil $\mathrm{C}$ and $\mathrm{N}$ stocks were higher in the soil with native vegetation $(\sim 90 \mathrm{Mg}$ $\mathrm{ha}^{-1} \mathrm{C}$ and $10 \mathrm{Mg} \mathrm{ha}^{-1} \mathrm{~N}$ ) as they expected. These authors emphasized that the land use change (i.e. castor bean soil cultivation) caused a reduction of approximately $50 \%$ into the soil $\mathrm{C}$ and $\mathrm{N}$ stocks on the first 10 years of the crop implantation, but the recovery into soil $\mathrm{N}$ contents was certified and this has kept soil $\mathrm{N}$ stocks for the next 40 years. Thus, we have used some molecular tools to explain the $\mathrm{N}$ stock maintenance into these soils with castor bean planting at the same time as we investigated the diazotrophic microorganism's roles.

DGGE allowed to detect the diazotrophs presence and defined the profile of the community structure in the different treatments evaluated. According to the hierarchical grouping, the samples tended to grouping according to the treatments, indicating two distinct groups, where the first connect the both samples CAA and CB-50 (Figure 1). The second group separated the four replicates of castor bean samples with 10 years of planting (M-10).

About the multidimensional analysis (Figure 2), the stress level applied to diazotrophs was 0.13 , guaranteeing the reliability of two-dimensional representation, which revealed a separation between the areas with different castor bean ages

The analysis of similarity (ANOSIM) generated results on the Pairwise test format (Table 2) and it seeking the differences among mean values of similarity between samples within the same area versus the differences among mean values of similarity between the areas evaluated. Results showed similarity between the Caatinga area and castor bean 50 years (global $\mathrm{R}=0.686 ; \mathrm{P}<0.001$ ). Values of $\mathrm{R}>0.75$ are interpreted as indicative of wellseparated groups; $\mathrm{R}>0.5$ as overlapping but clearly differentiated groups and $\mathrm{R}<0.25$ as little separated groups according to the Primer 7 program manual (CLARKE \& GORLEY, 2015).

Shannon $\left(H^{\prime}\right)$ and Simpson $(D)$ indexes showed a significant effect of treatments $\left(H^{\prime}, \mathrm{P}\right.$ $=0.0301, D, \mathrm{P}=0.0138)$. The greater diversity $\left(H^{\prime}\right)$ of diazotrophs was observed in soils with castor bean planting, whose values showed significant differences between CB-10 and CAA, with higher dominance $(D)$ in soils under CAA, differing significantly from soils under castor bean independently of time cultivation (Table 3 ).

The acetylene reduction assay indirectly proved this BNF by non-symbiotic diazotrophs, through the nitrogenase functional activity (Table 4). All the values were positive and did not show statistical differences among evaluated areas with presenting similarity between them. However, the $\mathrm{N}$-content

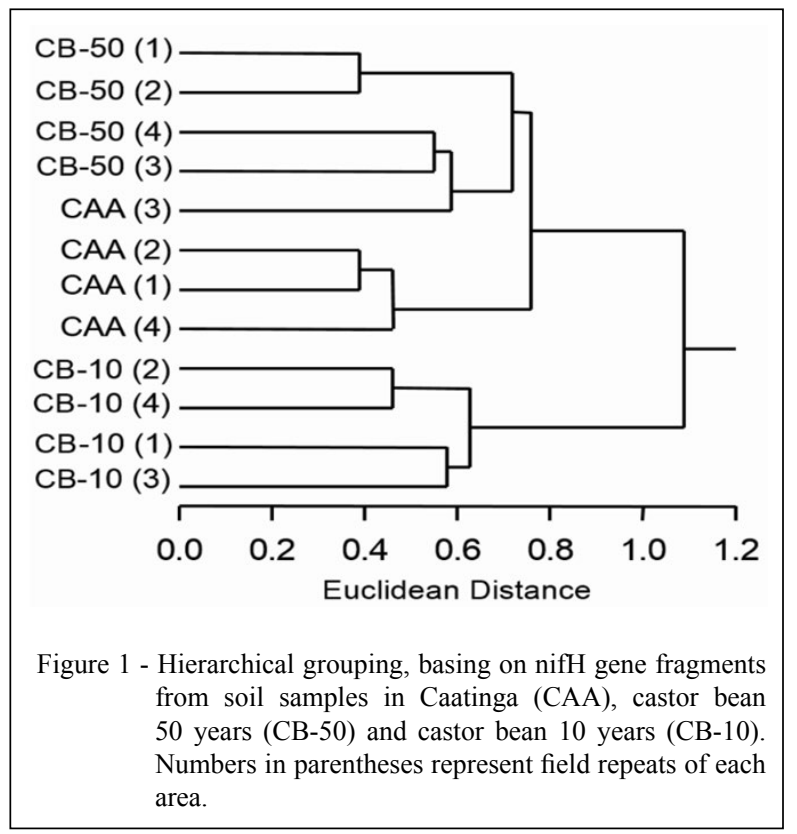

Ciência Rural, v.49, n.12, 2019. 


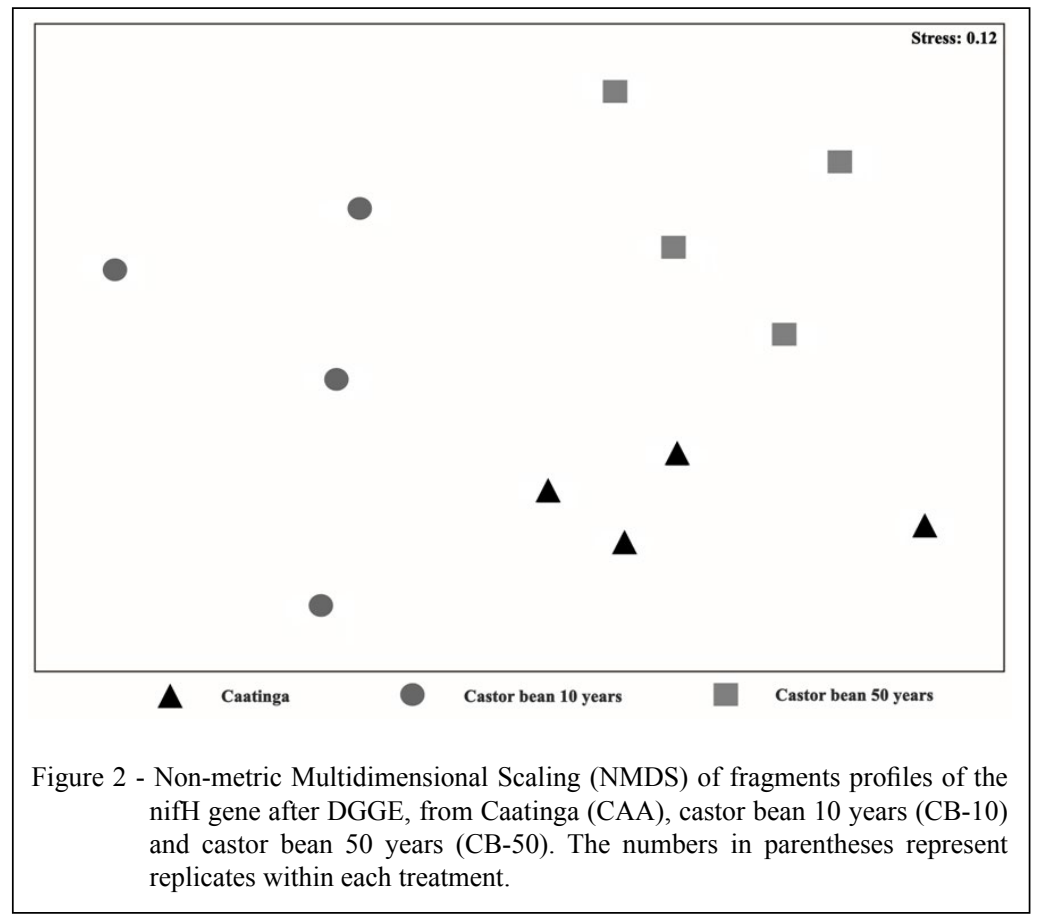

of soil microbial biomass was higher in the native vegetation and did not differentiate between 10 and 50 years of castor bean cultivation.

Absence of variation in soil $\mathrm{N}$ stocks founded by FRACETTO et al. (2012) and the evidence of nitrogenase activity confirmed that biological $\mathrm{N}$-fixation has been occurred and it was responsible for kept the N-cycling in these systems, after land use change for castor bean cultivation. Soil $\mathrm{N}$-content is determined by the relationship between the rate of $\mathrm{N}$-addition (i.e. by biological fixations and litter decomposition) and N-losses (i.e. by leaching mainly or ammonia volatilization) similarly to the C-accumulation dynamics (LAW et al., 2017). N-Biological fixation non-symbiotic can occur either

Table 2 - Pairwise test based on the diazotrophic nifH gene amplicons profiles from Caatinga (CAA), castor bean 10 years (CB-10) and castor bean 50 years (CB-50).

\begin{tabular}{lcc}
\hline Area & $\begin{array}{c}\text { Pairwise test } \\
(\mathrm{P}<0.05)\end{array}$ & $\begin{array}{c}\text { Significance level } \\
(\%)\end{array}$ \\
\hline CAA, CB-10 & 0.693 & 2.9 \\
CAA, CB-50 & 0.578 & 2.9 \\
CB-10, CB-50 & 0.865 & 2.9 \\
\hline
\end{tabular}

into the soil or on phylosphere and it has an adaptive advantage in relation to symbiotic fixation due to the lower specificity to the plant species interaction (MENG et al., 2019). Hence, the largest soil N stocks in the grasses or oilseed systems were due to N-entry into the soil-plant system from the BNF developed by free-living microorganisms.

In this semiarid region (north-central Bahia, Brazilian northeastern), the oldest areas cultivated with castor bean have been intercropped with maize (CB-50 treatment) and this may favor the N-storage into the soil by the grasses root system (FERRIERI et al., 2018) as demonstrated by KIFLE \& LAING (2016) in isolating free living diazotrophic bacteria from the maize roots. However, we understand that it did not has significantly influenced on the soil $\mathrm{N}$ stocks, since the soils with younger castor bean (10 years of planting) are absent from any intercropping and they can ensure the same $\mathrm{N}$-storage. We reinforce then, the hypothesis that the $\mathrm{N}$-maintenance into the soils with castor bean cultivation is carried out by pre-existing non-symbiotic microorganisms.

Molecular studies have not been demonstrated involving the microorganism's community profile (DGGE) to explain castor bean soil $\mathrm{C}$ and $\mathrm{N}$ stocks over time. Although, this type of molecular tool is widely used by the basic researches, it presented here efficient results as the differences 
Table 3 - Mean values of the Shannon $\left(\mathrm{H}^{\prime}\right)$ and Simpson (D) indexes from DGGE profiles of native Caatinga soils (CAA), castor bean 50 years (CB-50) and 10 years $(\mathrm{CB}-10)$.

\begin{tabular}{lcc}
\hline Area & $H^{\prime}$ & $D$ \\
\hline CAA & $2.0620 \mathrm{a}$ & $0.1295 \mathrm{~b}$ \\
CB-50 & $2.4574 \mathrm{ab}$ & $0.0882 \mathrm{a}$ \\
CB-10 & $2.5164 \mathrm{~b}$ & $0.0870 \mathrm{a}$ \\
\hline
\end{tabular}

Means followed by the same letter in the column did not differ by Tukey test $(P<0.05)$.
Table 4 - Mean values of acetylene reduction (ARA) and Nmicrobial biomass of native Caatinga soils (CAA), castor bean 50 years $(\mathrm{CB}-50)$ and 10 years $(\mathrm{CB}-$ $10)$

\begin{tabular}{lcc}
\hline Area & ARA $\left(\mathrm{nmol} \mathrm{g}^{-1} \mathrm{~h}^{-1}\right.$ of $\left._{2} \mathrm{H}_{4}\right)$ & $\mathrm{N}$-microbial $\left(\mathrm{mg} \mathrm{kg}^{-1}\right)$ \\
\hline CAA & $3.3 \mathrm{a}$ & $66 \mathrm{a}$ \\
CB-50 & $3.75 \mathrm{a}$ & $46 \mathrm{~b}$ \\
CB-10 & $3.71 \mathrm{a}$ & $44 \mathrm{~b}$ \\
\hline
\end{tabular}

Means followed by the same letter in the column did not differ by Tukey test $(P<0.05)$. in the structure of total diazotrophs in soils with castor bean planting and nif $\mathrm{H}$ gene had good amplification and representation of bands in the polyacrylamide gel. Moreover, nifH gene is present in all microorganisms fixing nitrogen that containing highly conserved regions among most diazotrophs (CHAKRABORTY et al., 2019).

With this, the nifH gene can be widely used in several researches with positive responses, even in environments with opposite temperatures to our research as demonstrated by IZQUIERDO \& NUSSLEIN (2006) that have been used successfully nifH sequences to estimate the diazotrophs richness in tropical forest soil in the arctic Tundra region. GABY \& BUCKLEY (2017) used the nifH gene in PCR quantitative (qPCR), finding good representability among their samples; although, our non-quantitative amplification reaction has also been well elaborating. Recently, some studies in tropical and dry lands environments related the contribution of organic nutrients with the energy required to nifH genes express activity (BARROS et al., 2018; PEREG et al., 2018). However, we emphasized that in our research all litter inputs are withdrawn by local farmers and; therefore, only residues from the roots systems of castor bean and maize are contributing with the energy necessary for the nifH gene activity on these soils.

It is known that soil $\mathrm{pH}$ and management intensity with soil organic matter reversal affects the abundance and structure of the diazotrophic community and its leading to a high difference in the amplicons profile would reveal changes in the functional activities of the microorganism's community (FARNELID et al., 2019). This condition would normally apply to soils fertilized or uncorrected acidity, but the castor bean soils evaluated are absent from any agricultural inputs and have a neutral $\mathrm{pH}$ range, favoring the optimal development conditions of the diazotrophs community and indirectly in the abundance of total microorganisms, as demonstrated by the N-microbial biomass estimate. According to TARDY et al. (2015) increased soil management intensity, such as castor bean cultivation, may increase microorganism diversity due to reduced competitive species exclusion, while in undisturbed environments, such as in the CAA treatment, the low diversity is a reflection of the dominance of adapted species through selection mechanisms.

The diazotrophs diversity of castor bean soils may have contributed to the functional recovery of these soils, after the stress caused by the implantation of the crop, even after years of nutrient export by maize intercropping with CB-50, evidencing the importance of functional redundancy for ecosystem maintenance and functioning (MENDES et al., 2015). GORLACHLIRA \& COUTINHO (2007) reported a great variety of diazotrophs bacteria, exclusively gram-positive spore-forming and some actinomycetes in soils with maize plantation in the northeastern semiarid region. The physiological versatility of these bacteria groups and the production of spores resistant to environmental effects allowed the population to survive through periods of water stress, high temperatures and dryness, keeping populations stable over the years.

TAN et al. (2003) and FENG et al. (2018) reported that environmental factors such as soil type, cultivation time and water regime are determinant on community structure and diazotrophs diversity. However, in our study the determining factor in the community structures between Caatinga and Castor ben soil cultivation was the land use change.

\section{CONCLUSION}

The present study was based on the data of total $\mathrm{C}$ and $\mathrm{N}$ stocks already published and the 
authors successfully used the DGGE technique to demonstrate differences between diazotrophic communities on soils with castor bean planting. The nif $\mathrm{H}$ gene amplification and nitrogenase activity confirmed both presence and activity of free-living diazotrophs in soils with castor bean cultivation.

Factors such as $\mathrm{pH}$, non-soil fertilization and land use change probably had no influence on the diazotrophic community structure and diversity, which are maintaining $\mathrm{N}$-stocks into the soil with castor bean planting over time.

\section{ACKNOWLEDGEMENTS}

The authors would like to thank the owners of Fazenda Floresta (Irecê-BA, Brazil) for allowing the field experimental activities. The research was financed in part by the Coordenação de Aperfeiçoamento de Pessoal de Nível Superior (CAPES), Brasil - Finance code 001. The author M.S.N. thanks to FAPEMA/CNPq (DCR-03572/16).

\section{DECLARATION OF CONFLICT OF INTERESTS}

The authors declare no conflict of interest. The founding sponsors had no role in the design of the study; in the collection, analyses, or interpretation of data; in the writing of the manuscript, and in the decision to publish the results.

\section{AUTHORS' CONTRIBUTIONS}

All authors contributed equally for the conception and writing of the manuscript. All authors critically revised the manuscript and approved of the final version.

\section{REFERENCES}

BARRON, A.R. et al. Molybdenum limitation of asymbiotic nitrogen fixation in tropical forest soils. Nature Geoscience, v.2, p.42-45, 2009. Available from: $<$ https://www.nature.com/articles/ ngeo366>. Accessed: May, 13, 2019. doi: 10.1038/ngeo366.

BARROS, F.M.D.R. et al. Silvopastoral systems drive the nitrogen-cycling bacterial community in soil. Ciência e Agrotecnologia, v.42, p.281-290, 2018. Available from: $<$ http://www.scielo.br/scielo.php? script=sci arttext\&pid $=$ S1413-70542018000300281 $>$. Accessed: May, 13, 2019. doi: $10.1590 / 1413-70542018423031117$

CHAKRABORTY, A. et al. Elevated level of arsenic negatively influences nif $\mathrm{H}$ gene expression of isolated soil bacteria in culture condition as well as soil system. Environmental Geochemistry and Health, p.1-14, 2019. Available from: $<$ https://link.springer. com/article/10.1007\%2Fs10653-019-00261-2>. Accessed: May, 13, 2019. doi: 10.1007/s10653-019-00261-2.

CLARKE, K.R; GORLEY, R.N. Getting started with PRIMER v7. Plymouth Marine Laboratory, 2015. Available from: <http:// updates.primer-e.com/primer7/manuals/Getting started with PRIMER_7.pdf $>$. Accessed: May, 13, 2019.
DEMBA DIALLO, M. et al. Polymerase chain reaction denaturing gradient gel electrophoresis analysis of the $\mathrm{N}_{2}$-fixing bacterial diversity in soil under Acacia tortilis ssp. Raddiana and Balanites aegyptiaca in the dryland part of Senegal. Environmental Microbiology, v.6, p.400-415, 2004. Available from: <https:// onlinelibrary.wiley.com/doi/abs/10.1111/j.1462-2920.2004.00577. $\mathrm{x}>$. Accessed: May, 13, 2019. doi: 10.1111/j.14622920.2004.00577.x

EMPRESA BRASILEIRA DE PESQUISA AGROPECUÁRIA - EMBRAPA. Manual de análises químicas de solos, plantas e fertilizantes. 2ed. Rev. ampl. Brasília, DF: Embrapa Informação Tecnológica, 672p. 2009. Available from: $<$ http://www.sidalc.net/ cgibin/wxis.exe/?IsisScript=AGB.xis\&method=post\&formato $=2 \&$ cantidad $=1 \&$ expresion $=\mathrm{mfn}=247764>$. Accessed: May, 13, 2019.

FARNELID, H. et al. Diverse diazotrophs are present on sinking particles in the North Pacific Subtropical Gyre. The ISME Journal, v.13, p.170-182, 2019. Available from: <https://www. nature.com/articles/s41396-018-0259-x>. Accessed: May, 13, 2019. doi: 10.1038/s41396-018-0259-x.

FENG, M. et al. Long-term fertilization influences community assembly processes of soil diazotrophs. Soil Biology and Biochemistry, v.126, p.151-158, 2018. Available from: $<$ https://www.sciencedirect.com/science/article/abs/pii/ S0038071718302761>. Accessed: May, 13, 2019. doi: 10.1016/j. soilbio.2018.08.021.

FERRIERI, R.A. et al. Managing the soil nitrogen cycle in agroecosystems. Soil Nitrogen Uses and Environmental Impacts, p.343, 2018. Available from: $<$ https://www.taylorfrancis. com/books/e/9781315228860/chapters/10.1201/b22044-14>. Accessed: May, 13, 2019.

FRACETTO, F.J.C. et al. Emissões de gases de efeito estufa na produção de mamona e de seus subprodutos. Revista Caatinga, v.28, p.90-98, 2015. Available from: <https://periodicos.ufersa. edu.br/index.php/caatinga/article/view/4468>. Accessed: May, 13, 2019. doi: 10.1590/1983-21252015v28n410rc.

FRACETTO, F.J.C. et al. Estoques de carbono e nitrogênio no solo cultivado com mamona na Caatinga. Revista Brasileira de Ciência do Solo, v.36, p.1545-1552, 2012. Available from: $<$ https://www.redalyc.org/html/1802/180224890019/>. Accessed: May, 13, 2019. doi: 10.1590/S0100-06832012000500019.

GABY, J.C; BUCKLEY, D.H. The use of degenerate primers in qPCR analysis of functional genes can cause dramatic quantification bias as revealed by investigation of nif $\mathrm{H}$ primer performance. Microbial Ecology, v.74, p.701-708, 2017. Available from: $<$ https:// link.springer.com/article/10.1007\%2Fs00248-017-0968-0>. Accessed: May, 13, 2019. doi: 10.1007/s00248-017-0968-0.

GORLACH-LIRA, K.; COUTINHO, H.D. Population dynamics and extracellular enzymes activity of mesophilic and thermophilic bacteria isolated from semi-arid soil of northeastern Brazil. Brazilian Journal of Microbiology, v.38, p.135-141, 2007. Available from: $<$ http://www.scielo.br/scielo.php?script=sci artte xt\&pid=S1517-83822007000100028 > . Accessed: May, 13, 2019. doi: 10.1590/S1517-83822007000100028.

Instituto Brasileiro de Geografia e Estatística-IBGE. Levantamento Sistemático da Produção Agrícola. 2017. Available from: $<$ https://sidra.ibge.gov.br/Tabela/1612\#resultado>. Accessed: May, 13, 2019 
IZQUIERDO, J.A; NÜSSLEIN, K. Distribution of extensive nifH gene diversity across physical soil microenvironments. Microbial Ecology, v.51, n.4, p.441-452, 2006. Available from: <https://link. springer.com/article/10.1007\%2Fs00248-006-9044-x>. Accessed: May, 13, 2019. doi: 10.1007/s00248-006-9044-x.

JOERGENSEN, R.G; BROOKES, P.C. Ninhydrin-reactive nitrogen measurements of microbial biomass in $0.5 \mathrm{M} \mathrm{K}_{2} \mathrm{SO}_{4}$ soil extracts. Soil Biology and Biochemistry, v.22 p.1031-1038, 1990. Available from: <https://www.sciencedirect.com/science/article/ abs/pii/003807179090027W>. Accessed: May, 13, 2019. doi: 10.1016/0038-0717(90)90027-W.

KACZMAREK, M.A. et al. Nitrogen reduction to ammonia on a biomimetic mononuclear iron centre: insights into the nitrogenase enzyme. Chemistry-A European Journal, v.24, p.5293-5302, 2018. Available from: <https://onlinelibrary.wiley.com/doi/ full/10.1002/chem.201704688>. Accessed: May, 13, 2019. doi: $10.1002 /$ chem. 201704688 .

KIFLE, M.H; LAING, M.D. Isolation and screening of bacteria for their diazotrophic potential and their influence on growth promotion of maize seedlings in greenhouses. Frontiers in Plant Science, v.6, p.1225, 2016. Available from: $<$ https://www. frontiersin.org/articles/10.3389/fpls.2015.01225/full>. Accessed: May, 13, 2019. doi: 10.3389/fpls.2015.01225.

LAW, Q.D. et al. Turfgrass selection and grass clippings management influence soil carbon and nitrogen dynamics. Agronomy Journal, v.109, p.1719-1725, 2017. Available from: <https:// dl.sciencesocieties.org/publications/aj/abstracts/109/4/1719>. Accessed: May, 13, 2019. doi: 10.2134/agronj2016.05.0307.

MENDES, L.W. et al. Soil-borne microbiome: linking diversity to function. Microbial Ecology, v.70, p.255-265, 2015. Available from: <https://link.springer.com/article/10.1007\%2 Fs00248-014-0559-2>. Accessed: May, 13, 2019. doi: 10.1007/ s00248-014-0559-2.

MENG, H. et al. Diazotrophic microbial community and abundance in acidic subtropical natural and re-vegetated forest soils revealed by high-throughput sequencing of nifH gene. Applied Microbiology and Biotechnology, v.103, p.995-1005, 2019. Available from: <https://ink.springer.com/article/10.1007/ s00253-018-9466-7>. Accessed: May, 13, 2019. doi: 10.1007/ s00253-018-9466-7.

PEREG, L. et al. Restoration of nitrogen cycling community in grapevine soil by a decade of organic fertilization. Soil and Tillage Research, v.179, p.11-19, 2018. Available from: <https:// www.sciencedirect.com/science/article/pii/S0167198718300096>. Accessed: May, 13, 2019. doi: 10.1016/j.still.2018.01.007.

PEREIRA \& SILVA, M.C. et al. Seasonal variations in the diversity and abundance of diazotrophic communities across soils. FEMS Microbiology Ecology, v.77, p.57-68, 2011. Available from: <https://academic.oup.com/femsec/article/77/1/57/528994>. Accessed: May, 13, 2019. doi: 10.1111/j.1574-6941.2011.01081.x.

POLY, F. et al. Improvement in the RFLP procedure for studying the diversity of nif $\mathrm{H}$ genes in communities of nitrogen fixers in soil. Research in Microbiology, v.152, p.95-103, 2001. Available from: <https://www.sciencedirect.com/science/article/
pii/S0923250800011724?via\%3Dihub>. Accessed: May, 13, 2019. doi: 10.1016/S0923-2508(00)01172-4.

SAS. User's Guide, Version 9.1. SAS Institute Inc., Cary, NC, 2003. Available from: <https://support.sas.com/documentation/ onlinedoc/91pdf/sasdoc_91/stat_ug_7313.pdf $>$. Accessed: May, $13,2019$.

SCHLOTER, M. et al. Microbial indicators for soil quality. Biology and Fertility of Soils, v.54, p.1-10, 2018. Available from: $<$ https:// link.springer.com/article/10.1007/s00374-017-1248-3>. Accessed: May, 13, 2019. doi: 10.1007/s00374-017-1248-3.

SHANNON, C.; WEAVER, W. The mathematical theory of communication. University of Illinois press. Urbana, USA, p.117, 1963. Available from: <http://www.magmamater.cl/MatheComm. pdf $>$. Accessed: May, 13, 2019.

SIMONET, P. et al. Frankia genus-specific characterization by polymerase chain reaction. Applied and Environmental Microbiology, v.57, p.3278-3286, 1991. Available from: <https:// www.ncbi.nlm.nih.gov/pmc/articles/PMC183960/pdf/aem000640232.pdf $>$. Accessed: May, 13, 2019.

SIMPSON, E.H. Measurement of diversity. Nature, v.163, p.688, 1949. Available from: <https://www.nature. com/articles/163688a0>. Accessed: May, 13, 2019. doi: $10.1038 / 163688 \mathrm{a} 0$.

SOIL SURVEY STAFF. Keys to Soil Taxonomy, $12^{\text {th }}$, ed. USDANatural Resources Conservation Service, Washington-DC, 2014.

TAN, Z. et al. Effect of $\mathrm{N}$-fertilization, plant genotype and environmental conditions on nif $\mathrm{H}$ gene pools in roots of rice. Environmental Microbiology, v.5, p.1009-1015, 2003. Available from: $\quad<$ https://onlinelibrary.wiley.com/doi/abs/10.1046/j.14622920.2003.00491.x?sid=nlm\%3Apubmed $>$. Accessed: May, 13, 2019. doi: 10.1046/j.1462-2920.2003.00491.x.

TARDY, V. et al. Shifts in microbial diversity through land use intensity as drivers of carbon mineralization in soil. Soil Biology and Biochemistry, v.90, p.204-213, 2015. Available from: $<$ https://www. sciencedirect.com/science/article/abs/pii/S0038071715002795>. Accessed: May, 13, 2019. doi: 10.1016/j.soilbio.2015.08.010.

VANCE, E.D. et al. An extraction method for measuring soil microbial biomass. Soil Biology and Biochemistry, v.19, p.703107, 1987. Available from: <https://www.sciencedirect.com/ science/article/abs/pii/0038071787900526>. Accessed: May, 13, 2019. doi: 10.1016/0038-0717(87)90052-6.

WANG, C. et al. Responses of soil N-fixing bacteria communities to invasive plant species under different types of simulated acid deposition. The Science of Nature, v.104, p.43, 2017. Available from: <https://link.springer.com/article/10.1007/s00114-017-14637>. Accessed: May, 13, 2019. doi: 10.1007/s00114-017-1463-7.

ZHANG, Y. et al. High light exposure on seed coat increases lipid accumulation in seeds of castor bean (Ricinus communis L.), a nongreen oilseed crop. Photosynthesis Research, v.128, p.125-140, 2016. Available from: <https://link.springer.com/ article/10.1007\%2Fs11120-015-0206-x>. Accessed: May, 13, 2019. doi: $10.1007 / \mathrm{s} 11120-015-0206-\mathrm{x}$. 